\title{
Laurocerasus officinalis Roem. fruit extract induces cell death through caspase mediated apoptosis in gastric cancer cell lines
}

\section{Laurocerasus officinalis Roem. meyve ekstrelerinin mide kanseri hücrelerinde kaspaz aracılı apoptoz yoluyla sitotoksik etkilerinin incelenmesi}

https://doi.org/10.1515/tjb-2020-0378

Received February 23, 2020; accepted October 22, 2020;

published online January 8, 2021

\section{Abstract}

Objectives: Laurocerasus officinalis Roem. fruits are traditionally used for several health problems. Although there are some studies about its antiproliferative effects on different cancer cells, no study was reported about its potential therapeutic efficacy against gastric cancers which is the most malignant disease in the digestive system with high morbidity and mortality.

Methods: This study was aimed to evaluate $L$. officinalis fruit extract phytochemical contents as well as to compare

*Corresponding author: Nihal Karakaş, Department of Medical Biology, School of Medicine, Istanbul Medipol University, Beykoz, Istanbul, Turkey; and Research Institute for Health Sciences and Technologies (SABITA), Istanbul Medipol University, Istanbul, Turkey, Phone: +90 21668151 00, E-mail: nkarakas@medipol.edu.tr. https://orcid.org/0000-0002-9096-1512

Mehmet Evren Okur, Department of Pharmacology, Faculty of Pharmacy, University of Health Sciences, Istanbul, Turkey, E-mail: evrenokurecz@gmail.com

Nurşah Öztunç, Research Institute for Health Sciences and Technologies (SABITA), Istanbul Medipol University, Istanbul, Turkey Derya Çiçek Polat, Department of Pharmaceutical Botany, Faculty of Pharmacy, Ankara University, Ankara, Turkey,

E-mail: polatd@ankara.edu.tr

Ayşe Esra Karadağ, Department of Pharmacognosy, School of Pharmacy, Istanbul Medipol University, Istanbul, Turkey; and Graduate School of Health Sciences, Anadolu University, Eskişehir, Turkey, E-mail: ayseesraguler@gmail.com anticancer effects on gastric cancer cells. The antioxidant activities were determined by ABTS and DPPH assays. Anticancer effects were measured by cell viability assays, then apoptotic proteins were analyzed by western blotting and flow cytometry.

Results: Laurocerasus officinalis fruit methanol extract showed moderate antioxidant activity by $\mathrm{ABTS}^{\circ}$ and $\mathrm{DPPH}^{*}$ assays. Significant cytotoxic activities and caspase mediated apoptosis were detected in the extract treated MKN-45 and AGS gastric cancer cells respectively while sparing healthy cells. Conclusion: Our results showed that the L. officinalis Roem. extract has significant anticancer efficacy on gastric cancer cell lines; therefore, it can be further studied to determine its potential therapeutic components.

Keywords: antioxidant activity; apoptosis; gastric cancer; Laurocerasus officinalis; Rosaceae.

öz

Giriş: Laurocerasus officinalis Roem. meyveleri halk arasında çeşitli sağlık problemlerine karşı kullanılmaktadır. Farklı kanser hücreleri üzerindeki antiproliferatif etkileri ile ilgili bazı çalışmalar olmakla birlikte, sindirim sistemindeki ciddi bir rahatsızlık olan, yüksek morbidite ve mortaliteye sahip mide kanserlerine karşı herhangi bir çalışma bildirilmemiştir.

Yöntem: $\mathrm{Bu}$ çalışma $L$. officinalis meyve ekstrelerinin fitokimyasal analizi ile beraber karşılaştırmalı olarak mide kanseri hücrelerine karşı sitotoksik etkilerinin incelenmesini amaçlamıştır. Antioksidan aktivite ABTS ve DPPH yöntemleriyle araştırılmıştır. Antikanser etkinliği ise hücre canlılığı yöntemi ile araştırılmış ve sonrasında apoptotik 
proteinleri western blot ve flow sitometre yöntemleri ile ölçülmüştür.

Sonuçlar: L. officinalis meyve metanol ekstresi, ABTS ve $D P P H$ testlerine göre orta düzeyde antioksidan aktivite göstermiştir. Sağlıklı hücrelerde sitotoksik etki gözlemlenmezken, ekstre uygulanmış MKN-45 ve AGS mide kanseri hücrelerinde önemli sitotoksik aktiviteler ve kaspaz aracılı apoptoz saptanmıştır.

Tartışma: Sonuçlar, L. officinalis Roem ekstresinin mide kanseri hücre hatları üzerinde önemli antikanser etkinliğine sahip olduğunu göstermiştir; bu nedenle, potansiyel terapötik bileşenlerini belirlemek için ileri çalışmalar gerçekleştirilebilecektir.

Anahtar kelimeler: Laurocerasus officinalis; Rosaceae; mide kanseri; apoptoz; antioksidan aktivite.

\section{Introduction}

Laurocerasus officinalis Roem. (synonym: Prunus laurocerasus L.) is a food plant of the Rosaceae family. It grows naturally in Turkey and is known as "laz kirazı, karayemiş or taflan". Cherry laurel is native of Central and Western Asia, Anatolia, and Southern Europe and cultivates in temperate regions and is mostly used as ornamental plant [1]. Its fruits are usually consumed as jam, marmalade, fruit juice, tea, and in canned or pickled styles [2]. Fruits and seeds are used in the treatment of kidney stones, stomach ulcers, bronchitis, strengthening the bones, the acid-base balance of blood (seeds), eczemas and hemorrhoids, and as a diuretic, antispasmodic, antitussive (fruits) as a folk medicine in Turkey [3]. The major bioactive components are 2-O- $\beta$-d-glucopyranosyl-2-hydroxyphenyl-acetic acid, $(+)$-catechin and kaempferol-3-O- $\beta$-d-xylopyranosyl-( $1 \rightarrow 2)$ $O-\beta$-d-glucopyranoside have been noticed in the cherry laurel leaves extract [4]. L. officinalis fruit stems nutritional and pharmaceutical value from its vanillic, caffeic, chlorogenic, and benzoic acid with fructose, glucose [5], mannitol, ascorbic acid, antocyanins [6] and tannin content [7].

Although many drugs have been developed for the treatment of cancers, there are concerns about the therapeutic effects and safety of these drugs. The major problem of chemotherapeutic drugs used as a standard treatment in various types of cancers is the toxicity [8]. However, products from plants have been proven to be effective and safe in the treatment of cancers. Therefore, cancer drug discoveries are also directed to plant derived products obtained from natural plants [9]. These products act as anti-cancer agents by interfering with the initiation, development, and progression of cancer through the modulation of various mechanisms including cellular proliferation, differentiation, apoptosis, angiogenesis, and metastasis [10]. Studies have greatly agreed on the protective effect of fruits and vegetables in reducing the risk of stomach cancer, because fruits and vegetables contain the antioxidant substances [11-13].

Laurocerasus officinalis is used for stomach ulcer treatment as a folk medicine in Turkey and therefore its contents make it a potential therapeutic candidate for different gastrointestinal problems.

Gastric cancer is a malignant disease and ranks fifth for cancer incidence and second for cancer deaths [14]. The underlying mechanisms of gastric cancer are mostly linked to Helicobacter Pylori (H. Pylori) infection and abundance of the $\mathrm{H}$. Pylori makes its mortality pattern variative for different ethnics. Eradication of H. Pylori provides a good prognosis of the disease [15-17].

Unfortunately, the infection is hard to clear by the host and results in a chronic inflammatory state with continued oxidative stress within the tissue. Reactive oxygen/nitrogen species are released by the effected immune and epithelial cells; then damage the surrounding tissue and lead to gastric carcinogenesis [18]. Therefore, H. Pylori behavior and host response determine the progress of the disease, and alternative treatment options are needed to overcome chemotherapy resistance developed by the bacterium [19].

There have been many anti-cancer studied on L. officinalis and showed a selective cytotoxic effect in lung, colon, prostate, liver, and cervical cancer cell lines [20-22]. But no studies have been found with anti-cancer activities against gastric cancer $L$. officinalis. In this study, we focused on its potential anti-cancer effects against gastric cancer since it can be eaten and in direct contact with the stomach. Besides cell viability assays, we showed apoptotic cell death by western blotting and Annexin V/PI stainings upon treatment with the extract.

In the present study, L. officinalis fruits total phenolic content and flavonoid contents were determined, afterward; their in vitro antioxidant and anti-cancer activities against gastric cancer showed that it can be further studied and characterized for therapeutic benefits.

\section{Materials and methods}

\section{Materials}

The standard chemicals were purchased from Sigma Chemical Co. (St. Louis, USA) and the HPLC-grade solvents were purchased from Merck. Methanol was purchased from Sigma-Aldrich, Germany. All other reagents and solvents used were of analytical grade. 


\section{Preparation of samples}

Laurocerasus officinalis fruits were collected from Ankara University, Ankara, Turkey (Date: 18.07.2017), and identified by Derya Çiçek Polat. L. officinalis fruit, which is dark purple, were pureed and extracted with methanol on a magnetic stirrer (Heidolph MR3001, Germany) (250 g sample, $400 \mathrm{~mL} \times 3$ days) followed by filtration [1]. The extract was distilled using an evaporator (Heidolph WB2000, Germany).

\section{Total phenolic and flavonoid contents}

Folin Ciocalteu technique was used to detect total phenolics of the fruit extract. The mixture was prepared with fruit extract $(5 \mathrm{~mL})$, FolinCiocalteau's reagent $(0.25 \mathrm{~mL})$, and $\mathrm{Na}_{2} \mathrm{CO}_{3}(0.2 \mathrm{~mL})$ and kept for $15 \mathrm{~min}$ at $45^{\circ} \mathrm{C}$. The absorbance reading of samples was performed at $765 \mathrm{~nm}$. A calibration curve $\left(\mathrm{R}^{2}=0.981\right)$ was used for calculating the total phenolic content (TPC) of the extract and the outcome was showed as mg gallic acid equivalent (gae)/100 g extract $[1,23,24]$. The basis of this method is based on the redox reaction of phenolic compounds in the basic medium, reducing the Folin-Ciocalteu reagent and converting the phenolic compounds into oxidized form. The color intensity of the resulting complex is directly proportional to the concentration of phenolic substances [25].

The aluminum chloride colorimetric method was performed to detect the total flavonoid content of $L$. officinalis fruit extract. $50 \mu \mathrm{L}$ of the extract was mixed with methanol (up to $1 \mathrm{~mL}$ ) and added $4 \mathrm{~mL}$ water, then $5 \% \mathrm{NaNO}_{2}$ solution; $10 \% \mathrm{AlCl}_{3}$ solution was added. Afterward, $\mathrm{NaOH}(1 \mathrm{~mol} / \mathrm{L})$ was added and water was used to adjust to $10 \mathrm{~mL}$ (total volume). After waiting, the absorbance of the mix was read at $510 \mathrm{~nm}$. The content of flavonoid was detected by the calibration curve $\left(R^{2}=0.9978\right)$ [26] and the outcome was displayed as $\mathrm{mg}$ quercetin equivalent (qe)/100 g extract. All experiments were done in triplicate. The basis of this method is that Aluminum chloride forms acid stable complexes with the $\mathrm{C}-4$ keto groups and either the $\mathrm{C}-3$ or $\mathrm{C}-5$ hydroxyl group of flavonoids. Moreover, aluminum chloride is also complex with ortho-dihydroxyl groups of A or B-rings of flavonoids. The results are usually given as equivalent to standard flavonoids quercetin [27].

\section{DPPH scavenging assay}

To determine the $L$. officinalis fruit extract antioxidant ability, the DPPH (2,2-diphenyl-1-picrylhydrazyl) radicals were utilized according to the spectrophotometric protocol $[1,28]$. The absorbance was read at $517 \mathrm{~nm}$ using a spectrophotometer. The radical scavenging activity was calculated according to the following equation:

$\mathrm{DPPH} \cdot \mathrm{RSA} \%=([$ Absorbance control - Absorbance test sample $] /$ [Absorbance control]) $\times 100$

All experiments were done in triplicate. Ascorbic acid was served as a positive control. $\mathrm{IC}_{50}$ rates were detected from a calibration curve [23].

\section{ABTS scavenging assay}

2,2'-azino-bis-3-ethylbenzthiazoline-6-sulfonic acid (ABTS) radical scavenging activity of $L$. officinalis was determined according to Re et al. [29]. Stock ABTS. solution was composed by reacting aqueous of
ABTS. with potassium persulfate solution. The mixed solution was incubated for $12-16 \mathrm{~h}$ in the dark at room temperature. The absorbance of reaction mixtures was measured at $734 \mathrm{~nm}$. Three independent experiments were performed. An analog of vitamin E, Trolox was used as the positive control $[1,26]$. The results were compared with Trolox and expressed as $\mathrm{IC}_{50}$ as follows:

$\%$ ABTS inhibition $=([$ Absorbance control - Absorbance test sample]/[Absorbance control] $) \times 100$

\section{LC-MS analysis}

For Liquid Chromatography Mass Spectroscopy (LC-MS) analysis the extract was dissolved in methanol and filtered. The extract was analyzed using LC-MS (1200LC, Agilent). Ionization was achieved in negative mode with ESI. For the chromatropic separation, LC-MS was run on $4.6 \times 250 \mathrm{~mm}$, i.d. $5 \mu \mathrm{m}$ particle size, octadecyl silica gel analytical C18 column, and its temperature was maintained at $40{ }^{\circ} \mathrm{C}$. The elution gradient consisted of mobile phases were A: Acetonitrile:Water $(10: 90, v / v)$ and B: Acetonitrile:Water $(90: 10 v / v)$. The gradient established in the time frame $0-40 \mathrm{~min}, \mathrm{~B} \% \mathrm{15}-100$. The solvent flow rate is maintained at $0.7 \mathrm{~mL} / \mathrm{min}$. The injection volume is $20 \mu \mathrm{L}$. The range of 100-1000 amu was scanned and recorded for MS analysis [30].

\section{Cell culture}

AGS-human gastric adenocarcinoma (ATCC, \#CRL-1739) cell line and Human Primary Dermal Fibroblasts (HDFa) (ATCC, \# PCS-201-012) were purchased from ATCC (U.S.). The human gastric adenocarcinoma cell line, MKN-45 (DSMZ, \#ACC409) was obtained from DSMZ (Germany). AGS and MKN-45 cells were grown in RPMI and DMEM (Gibco) medium respectively in the presence of $10 \%$ fetal bovine serum (Gibco) with the addition of $1 \%$ antibiotics (penicillin/streptomycin) in $5 \% \mathrm{CO}_{2}$ incubator (at $37^{\circ} \mathrm{C}$ ). The subculture of cells was performed every $4-5$ days as the cells reach the confluency. The cells were harvested from the flask with Trypsin/EDTA $0.25 \%$ (Gibco) and for cell viability assays, $5 \times 10^{3}$ cells/well were seeded into 96 black well plates (Corning).

\section{Cell viability assays}

Extracts were dissolved in growth medium and filtered using $0.20 \mu \mathrm{m}$ PES filters (Sarstedt) to prepare stock solutions, and for serial dilutions as a final concentration to normalize measurements. After seeding into 96 well plates, for $24 \mathrm{~h}$, cells were incubated in $5 \% \mathrm{CO}_{2}\left(37^{\circ} \mathrm{C}\right)$ incubator. Then, $1-10 \mathrm{mg} / \mathrm{mL}$ of $L$. officinalis extract was added as triplicates. After $48 \mathrm{~h}$ of treatment, Cell Titer Glo reagent (Promega) added into each well according to the manufacturer's guide, and viable cells were determined by reading luminescence signal under SpectraMax i3x Multi-Mode Detection Platform.

\section{Western blotting}

Cells were seeded at a density of $2 \times 10^{5}$ cells/well into six well plates for western blot sample collection. Then incubated at $37^{\circ} \mathrm{C}$ in $5 \% \mathrm{CO}_{2}$ for $24 \mathrm{~h}$. The culture medium was discarded, and cells were treated with $0 \mathrm{mg} / \mathrm{mL}$ (control) or $5 \mathrm{mg} / \mathrm{mL}$ of $L$. officinalis extract (Control wells were treated with an equal amount of extract solvent; $\left.\mathrm{dH}_{2} \mathrm{O}\right)$. After $48 \mathrm{~h}$ of 
treatment, protein lysates were obtained using Ripa lysis buffer (Thermo Fischer Scientific; \#89900) from each well. Protein samples were equally loaded $(25 \mu \mathrm{g} /$ well $)$ and run on SDS-PAGE. Then, Bio-Rad semi-dry western blotting protocol was applied. Then the membrane was incubated with blocking buffer ( $5 \%$ BSA or $5 \%$ skim milk accordingly) for $1 \mathrm{~h}$ at room temperature. Afterward, the membrane was probed with antibodies against PARP, caspase- 3 and $\beta$-actin (anti-PARP (CST; \#9542), anti-cleaved caspase 3 (CST; \#9161), (CST \#4970), anti-rabbit (CST; \#7074) and HRP conjugated anti-mouse (GenDEPOT; \#W3903) antibodies were used). The first antibody incubation was performed at $4^{\circ} \mathrm{C}$ for overnight and after washing with TBST three times, membranes were then probed with HRP conjugated secondary antibodies for $2 \mathrm{~h}$ at room temperature. The membranes were washed and incubated with a 1:1 ratio of Clarity Western ECL Substrate (Bio-Rad), then analyzed for protein bands by ChemiDoc-MP (Bio-Rad).

\section{Annexin V/Propidium lodide apoptosis stainings}

After seeding into $100 \times 20 \mathrm{~mm}$ culture dishes, cells were incubated at $37{ }^{\circ} \mathrm{C}$ in $5 \% \mathrm{CO}_{2}$ for $24 \mathrm{~h}$. Then the culture medium was discarded, and cells were treated with $0 \mathrm{mg} / \mathrm{mL}$ (control) and $5 \mathrm{mg} / \mathrm{mL}$, of $L$. officinalis extract. To detect early apoptotic cells, an earlier time point was determined than the viability assays. Therefore, after $36 \mathrm{~h}$ of treatment with L. officinalis extract, Annexin V-FITC/Propidium Iodide (PI) early apoptosis double staining protocol was applied according to manufacturer's instructions (CST \#6592 Annexin V-FITC Early Apoptosis Kit). Then, early apoptotic, late apoptotic, necrotic, and live cell percentages were determined through flow cytometry analysis.

\section{Statistical analysis}

All statistical comparisons of antioxidant activity studies were performed by one-way ANOVA followed by Dunnett's tests. $p<0.05$ was considered statistically significant. For in vitro cell based assays, statistical comparisons were performed by unpaired Student's t-test assuming equal variance. Differences were considered as statistically significant at $0.003<p^{\star} \leq 0.005$ and $0.0005<p^{\star \star} \leq 0.003 ; p^{\star \star \star} \leq 0.0003$ and $0.01<\mathrm{p}^{\#} \leq 0.05$. Data were expressed as means \pm S.E.M.

\section{Results}

\section{Phenolic and flavonoid contents}

Total phenolics were calculated by using the Folin-Ciocalteu method. Total flavonoids in the fruit extract were measured using the aluminum chloride colorimetric method. L. officinalis fruit total phenolic and flavonoid content were detected, and the results which are similar to our previous study [1] are given in Table 1.

\section{In vitro antioxidant assays}

The free radical scavenging activity of the extract was determined using ABTS and DPPH experiments and the
Table 1: Total flavonoid and phenolic content of $L$. officinalis fruit extract.

\begin{tabular}{lrr}
\hline & $\begin{array}{r}\text { Total flavonoid content } \\
\text { mg QE/100 g extract }\end{array}$ & $\begin{array}{r}\text { Total phenolic content } \\
\text { mg GAE/100 g extract }\end{array}$ \\
\hline $\begin{array}{l}\text { L. officinalis } \\
\text { fruit extract }\end{array}$ & $502.10 \pm 6.85 \mathrm{mg}$ & $461.31 \pm 4.98 \mathrm{mg}$ \\
$\mathrm{qe} / 100 \mathrm{~g}$ & $\mathrm{gae} / 100 \mathrm{~g}$ \\
\hline
\end{tabular}

outcomes are assembled in Table 2, as previously reported [1]. The antioxidant activity of $L$. officinalis was investigated by similar and different methods. When the results were compared, similar results were observed in similar studies. It is known that the collection of the plant, its drying, the area it was grown, and the extraction method even caused a change in the antioxidant capacity. Therefore, some minor differences can be observed between previous studies [6, 31-34].

\section{Qualitative chromatographic analysis by LC-MS}

The flavonoid compositions of the methanol extract were detected by LC/MS. Standards were detected according to mass analyses and qualitative analyses using reversedphase chromatography. The flavonoid components of L. officinalis fruit were characterized as luteolin, quercetin, and apigenin (Figure 1, Figure 2) (Table 3).

\section{Cell viability assays}

\section{Treatment with $L$. officinalis fruit extract led to significantly decreased cell viability in MKN45 and AGS human gastric cancer cell lines}

Cytotoxic effects of the L. officinalis on MKN45 (human gastric cancer cell line), AGS (gastric adenocarcinoma cell line), and primary human fibroblast cells by measuring their metabolically active state. According to our findings, cell viability significantly decreased when treated with

Table 2: ABTS and DPPH scavenging activities of $L$. officinalis extract.

\begin{tabular}{lrr}
\hline & \multicolumn{1}{c}{ L. officinalis extract } & References \\
\cline { 2 - 3 } & \multicolumn{2}{c}{ IC50 $\pm \mathbf{S D}, \mathbf{~ m g} / \mathbf{m L}$} \\
\hline ABTS & $2.44 \pm 0.21$ & 2.986 (trolox) \\
DPPH & $2.95 \pm 0.09$ & 3.767 (ascorbic acid) \\
\hline
\end{tabular}



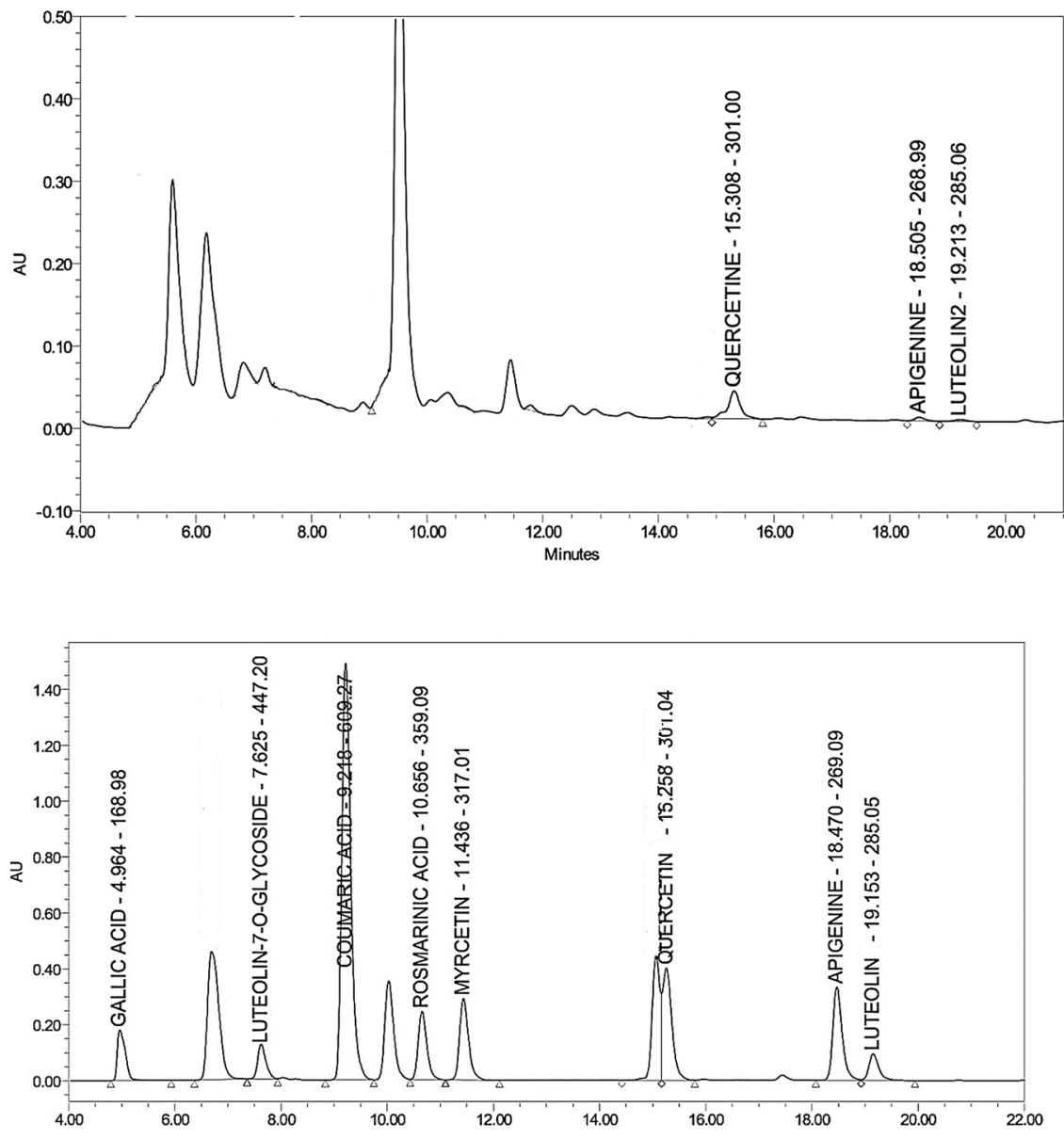

Figure 1: L. officinalis fruit methanol extract LC-MS chromatogram.
Figure 2: Standard chromatogram of LC-MS. Standards:1, gallic acid (R.T. 4.96); 2, Luteolin-7-o-glycoside (R.T. 7.62); 3, Coumaric acid (R.T. 9.21); 4, Rosmarinic acid (R.T. 10.65); 5, Myrcetin (R.T. 11.43); 6, Quercetin (R.T. 15.25); 7, Apigenine (R.T. 18.47); 8 Luteolin (R.T. 19.15) (R.T.=Retantion time).
Table 3: L. officinalis methanol extract flavonoid compounds.

\begin{tabular}{lrr}
\hline Compounds & RT & Base peak $(\boldsymbol{m} / \mathbf{z})$ \\
\hline Quercetine & 15.418 & 314.99 \\
Apigenine & 18.502 & 269.12 \\
Luteolin & 19.213 & 285.06 \\
\hline
\end{tabular}

$5-10 \mathrm{mg} / \mathrm{mL}$ extract in both MKN-45 and AGS cancer cell lines. Treatment of gastric cancer cell lines with $5 \mathrm{mg} / \mathrm{mL}$ L. officinalis extract showed $65.6 \%(\mathrm{p}=0.0031)$ and $25.2 \%$ (0.0038) significantly decreased cell viability in AGS and MKN-45 cells, respectively. Besides that, $10 \mathrm{mg} / \mathrm{mL}$ extract of $L$. officinalis led to highly decreased viability of cells with $1.1 \%$ in MKN45 and 27.4\% in AGS cell lines $(\mathrm{p} \leq 0.0003)$ Conversely, treatment of primary human fibroblast cells with the same concentrations $(5-10 \mathrm{mg} / \mathrm{mL})$ of $L$. officinalis extracts showed statistically non-significant cytotoxicity (Figure 3A). Accordingly, $L$. officinalis extract showed $3.770 \mathrm{mg} / \mathrm{mL} ; 5.606 \mathrm{mg} / \mathrm{mL}$ and $29.42 \mathrm{mg} / \mathrm{mL}$ IC $_{50}$ values for MKN-45; AGS and primary human fibroblast cells respectively (Figure 3B).

\section{Detection of apoptosis}

\section{L. officinalis extract induced apoptosis in both AGS and MKN-45 cell lines through caspase- 3 and PARP cleavages}

Apoptosis was analyzed in $5 \mathrm{mg} / \mathrm{mL}$ extract treated MKN-45 and AGS gastric cancer cell lines. Compared to control treatments $(0 \mathrm{mg} / \mathrm{mL})$, cleaved PARP and cleaved caspase- 3 presence were detected in $L$. officinalis extract treated AGS and MKN-45 gastric cancer cell lines (Figure 4A). According to Image J analysis of AGS cell line, cleaved PARP intensity increased approximately four folds $(p \leq 0.0001)$, and cleaved caspase three intensity increased approximately eight folds $(\mathrm{p}=0.0025)$ (Figure 4B). In L. officinalis extract treated MKN-45 cell 

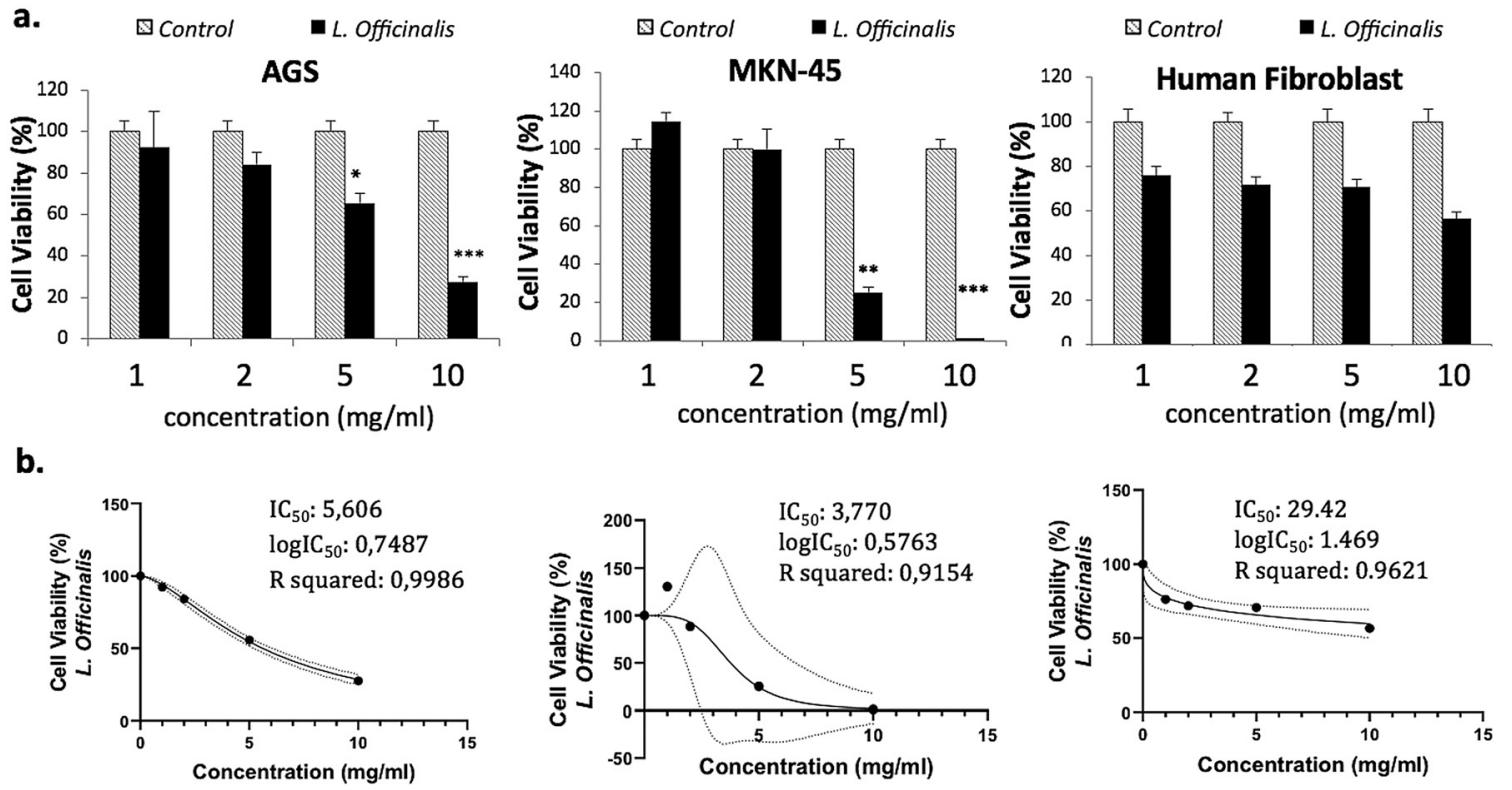

Figure 3: Cytotoxic effects of $L$. officinalis extracts on MKN45 and AGS gastric cancer cell lines and primary human fibroblast cells. Cell viability of a) AGS and MKN-45 cell line decreased in a concentration dependent manner upon $48 \mathrm{~h}$ treatment with $1-10 \mathrm{mg} / \mathrm{mL}$ L. officinalis extracts. Decrease in viability of fibroblast cells were found statistically not significant. Cell viability assays were performed as three independent experiments. Data are expressed as \pm SEM. Differences were considered as statistically significant at $0.003<p^{\star} \leq 0.005$ and $0.0005<p^{\star *} \leq 0.003$; and $p^{\star \star *} \leq 0.0003$. b) Normalize of dose vs. response graphs and $I_{50}$ values of AGS; MKN45 cell lines and primary human fibroblast cells. Accordingly, L. officinalis extract showed $\mathrm{IC}_{50}$ values of $3.770 \mathrm{mg} / \mathrm{mL}$ in MKN45 cell line; $5.606 \mathrm{mg} / \mathrm{mL}$ in AGS cell line; and $29.42 \mathrm{mg} / \mathrm{mL}$ in primary human fibroblast cells.

line; cleaved PARP intensity increased approximately one and a half folds ( $\mathrm{p}=0.0029)$ and cleaved caspase-3 intensity increased approximately five folds $(p=0.0010)$ (Figure 4C).

These data demonstrated the cleavage of apoptotic proteins and biochemical verification of cell death induced by $L$. officinalis extract in both AGS and MKN-45 gastric cancer cell lines. Additionally, caspase cleavage showed that $L$. officinalis extract induced cell death occurs in a caspase dependent manner.

\section{Apoptotic cell populations were determined in L. officinalis fruit extract treated AGS cell line}

We analyzed the apoptotic phase of cell populations in L. officinalis extract treated AGS gastric adenocarcinoma cell line. Different from cell viability assays, AGS cells were either treated with distilled water and $5 \mathrm{mg} / \mathrm{mL}$ of $L$. officinalis just for $36 \mathrm{~h}$ to track early apoptotic cells as well as late apoptotic cells using Annexin V-FITC Early Apoptosis Detection Kit (CST, U.S.). According to staining, L. officinalis extract treated AGS cells showed a shift from alive to death cell state, which is significantly determined as apoptotic cells either from early or late stages (Figure 5A, B). The quantitative analysis was performed and when compared to control cells, viable cells decreased from 89.65 to $66.22 \%$, and early apoptotic cells increased from 1.55 to $19.77 \%$, while late apoptotic cells increased from 4.78 to $11.78 \%$. Necrotic cell increase in population was not found statistically significant (from 4.02 to 2.23\%) (Figure 5C).

\section{Discussion}

In this study, we evaluated the potential use of $L$. officinalis fruit methanol extract against gastric cancer cell lines as it is one of the most malignant cancers studied and traditionally used in Turkey for the treatment of different types of human illness, especially for gastrointestinal problems $[6,33,35,36]$. Firstly, $L$. officinalis fruits TPC and TFC were determined and they have been investigated with respect to their in vitro antioxidant and anti-cancer activities against gastric cancer.

In our study, we found the total phenolic compounds and total flavonoids which are responsible for antioxidant activity were also rich in fruits.

The antioxidant activities of fruits were measured using the ABTS and DPPH methods which are most 
a.
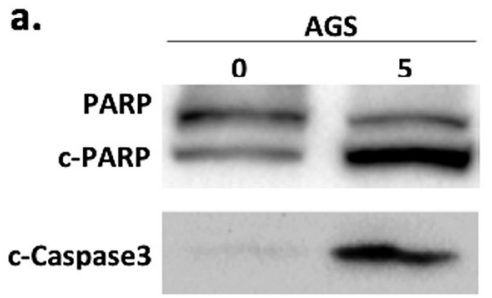

$\alpha$-tubulin

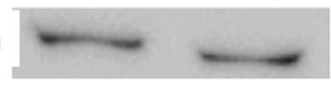

b.

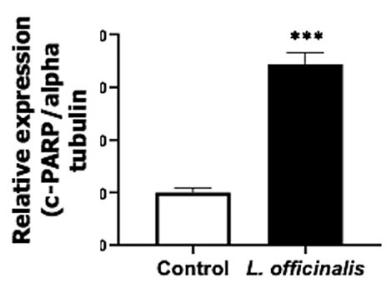

C.
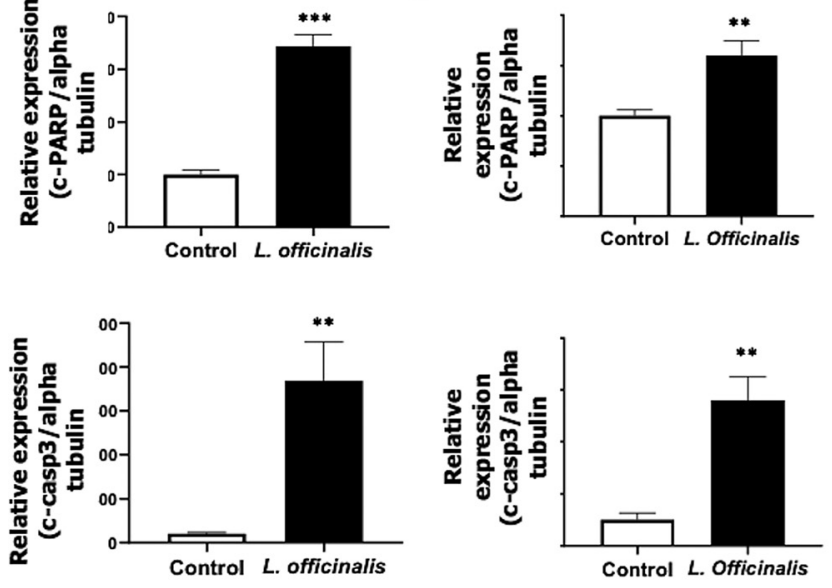

a.

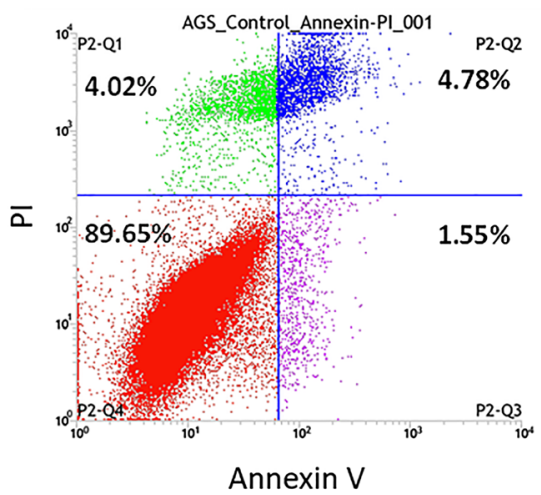

b.

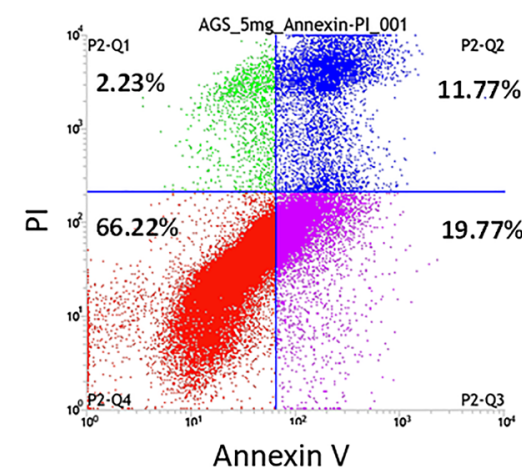

C.

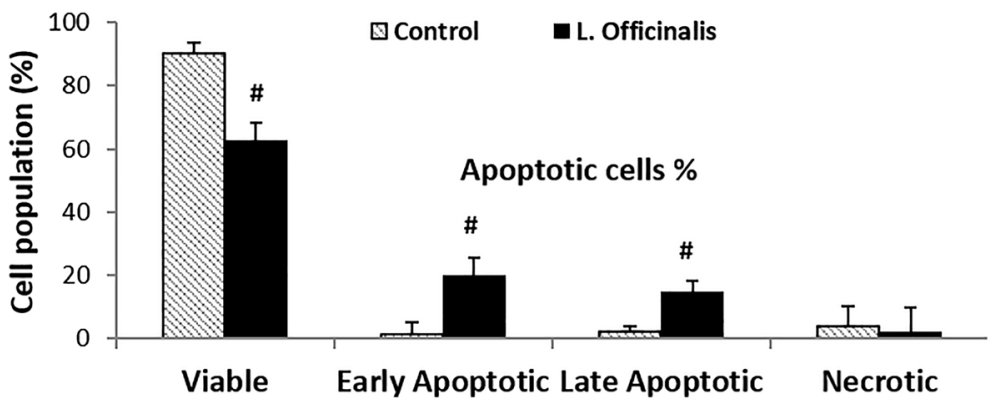

$\mathrm{mg} / \mathrm{ml}$ L. Officinalis

$116 \mathrm{kDa}$

$89 \mathrm{kDa}$

$17 \mathrm{kDa}$

$52 \mathrm{kDa}$

Figure 4: Western blot analysis of cell death in L. Officinalis fruit extract treated AGS and MKN45 gastric cancer cell lines. a) AGS and MKN45 gastric cancer cell lines were treated with distilled water $(0 \mathrm{mg} / \mathrm{mL}$ ) (left band) and $5 \mathrm{mg} / \mathrm{mL}$ of $L$. Officinalis (right band) for $48 \mathrm{~h}$ to detect apoptosis. In comparison with control bands $(0 \mathrm{mg} / \mathrm{mL})$, cleaved PARP and cleaved caspase three presence were detected in $5 \mathrm{mg} / \mathrm{mL}$ treatments. According to Image J analysis of b) AGS and c) MKN-45 gastric adenocarcinoma cell lines; cleaved PARP and cleaved caspase- 3 bands were detected as compared to control treatments. Data are expressed as \pm SEM. Differences were considered as statistically significant at $0.0005<p^{\star \star} \leq 0.003$; and $p^{\star \star \star} \leq 0.0003$. Experiments were performed as triplicates and band densities were normalized to actin controls using image J analysis.
Figure 5: Flow cytometry analysis of apoptosis in $5 \mathrm{mg} / \mathrm{mL}$ L. officinalis treated AGS gastric adenocarcinoma cell line. AGS cells were either treated with a) distilled water (left) or b) $5 \mathrm{mg} / \mathrm{mL}$ of L. officinalis (right) for $36 \mathrm{~h}$ to detect early apoptotic cells using Annexin V-FITC Early Apoptosis Detection Kit (CST, U.S.). Pannels P2-Q1; P2-Q2; and P2-Q3 indicate necrotic cells; late apoptotic cells, and early apoptotic cells respectively. Each staining was performed as triplicates. Data are expressed as \pm SEM and differences were considered as statistically significant at $0.01<\mathrm{p}^{\#} \leq 0.05$. common for antioxidant activity. These methods are also used to estimate the antioxidant activity because of the relatively short time required for analysis [34]. Many antioxidant studies have been conducted on $L$. officinalis and reported to be related to the total amount of flavonoids and phenolic compounds. Compared with these other 
studies, it has been shown to have a high antioxidant effect because of flavonoids and phenolic compounds like other studies [6, 31-34, 37].

Oxidative stress causes many diseases such as gastric diseases [38, 39]. Many studies have shown that plant components especially flavonoids can be effective and protective against oxidative damage [40, 41]. The flavonoid compositions of the fruit extract were determined by LC/MS analyses. The flavonoid components of the extract were characterized as luteolin, quercetin, and apigenin. Quercetin has been high antioxidant activity, which is a member of the flavonoid's family. It is the most effective scavenger of ROS [42]. Some studies have shown that quercetin is effective against gastric cancer [43, 44]. And also previous studies have shown that luteolin and apigenin also have effective activity for gastric cancer [45-48].

In the present study, the cytotoxic activity of the extract can be thought to be due to these flavonoid group compounds. In previous cytotoxic activity studies, it can be realized that the cytotoxicity may cause by flavonoids $[49,50]$. Previous studies have shown that $L$. officinalis fruits have a selective cytotoxic effect in lung, colon, prostate, liver, and cervical cancer cell lines and also in these studies indicated that the effect was caused by the phenolic compounds and flavonoids having antioxidant effects [20-22].

Our results revealed that ranging from 5 to $10 \mathrm{mg} / \mathrm{mL}$ concentrations of the extracts induce highly significant cell death in AGS and MKN-45 cell lines whilst preserving human fibroblasts healthier. We also investigated the background of cytotoxicity of the extract in terms of cell death pattern. Regarding LC/MS findings, luteolin, quercetin and apigenin contents of L. Officinalis methanol extract, might lead to apoptotic cell death in gastric cancer cells when treated. Protein cleavages (PARP and caspase 3) of the apoptotic cascade showed that the apoptosis caused by the extracts follows a caspase dependent manner. Furthermore, when the apoptotic cell population was analyzed via Annnexin V/PI stainings, we detected a statistically significant shift to apoptotic cell copopulation from live cell state (including both early and late apoptosis stages).

These findings indicate that as well as antioxidant activities, $L$. officinalis fruit extracts have anti-cancer effects against gastric cancer and when further studied, the active components can be an alternative or adjuvant to standard chemical drugs used in the clinics. Since many of the active phytochemicals are toxic to normal cells, cancer selective behavior of $L$. officinalis fruit extract for certain concentrations can be promising for translational approaches and $L$. officinalis can be potentially used against several cancers upon investigation. For this reason, the results of this study have a novelty to further study in detail and suggest to examine L. officinalis fruit methanol extract contents as potential anti-cancer therapeutic candidates.

Research funding: None declared.

Author contributions: All authors have accepted responsibility for the entire content of this manuscript and approved its submission.

Competing interests: The authors declare no conflict of interest.

\section{References}

1. Ayla S, Okur ME, Günal MY, Özdemir EM, Çiçek Polat D, Yoltaş A, et al. Wound healing effects of methanol extract of Laurocerasus officinalis Roem. Biotech Histochem 2019;94:180-8.

2. İslam A. 'Kiraz' cherry laurel (Prunus laurocerasus). N Z J Crop Hortic Sci 2002;30:301-2.

3. Yeşilada E, Sezik E, Honda G, Takaishi Y, Takeda Y, Tanaka T. Traditional medicine in Turkey IX: folk medicine in north-west Anatolia. J Ethnopharmacol 1999;64:195-210.

4. Küpeli Akkol E, Kırmızıbekmez H, Küçükboyacı N, Gören AC, Yesilada $\mathrm{E}$. Isolation of active constituents from cherry laurel (Laurocerasus officinalis Roem.) leaves through bioassay-guided procedures. J Ethnopharmacol 2012;139:527-32.

5. Var M, Ayaz A. Changes in sugar composition in cherry laurel (CV oxygemmis) fruit during development and ripening. Pakistan J Bot 2004;36:389-94.

6. Kolayli S, Küçük M, Duran C, Candan F, Dinçer B. Chemical and antioxidant properties of Laurocerasus officinalis Roem.(cherry laurel) fruit grown in the Black Sea region. J Agric Food Chem 2003;51:7489-94.

7. Colak A, Özen A, Dincer B, Güner S, Ayaz FA. Diphenolases from two cultivars of cherry laurel (Laurocerasus officinalis Roem.) fruits at an early stage of maturation. Food Chem 2005;90:801-7.

8. Livshits Z, Rao RB, Smith SW. An approach to chemotherapyassociated toxicity. Emerg Med Clin North Am 2014;32:167-203.

9. Demain AL, Vaishnav P. Natural products for cancer chemotherapy. Microb Biotechnol 2011;4:687-99.

10. Rajesh E, Sankari L, Malathi L, Krupaa J. Naturally occurring products in cancer therapy. J Pharm BioAllied Sci 2015;7:183.

11. Serafini M, Bellocco R, Wolk A, Ekström AM. Total antioxidant potential of fruit and vegetables and risk of gastric cancer. Gastroenterology 2002;123:985-91.

12. Metere A, Giacomelli L. Absorption, metabolism and protective role of fruits and vegetables polyphenols against gastric cancer. Eur Rev Med Pharmacol Sci 2017;21:5820-58.

13. Borek C. Dietary antioxidants and human cancer. Integr Canc Ther 2004;3:333-41.

14. Venerito M, Link A, Rokkas T, Malfertheiner P. Gastric cancer - clinical and epidemiological aspects. Helicobacter 2016; 21:39-44.

15. Suzuki H, Mori H. Gastric cancer after helicobacter pylori eradication. Jpn J Canc Chemother 2018;45:1123-7. 
16. Guggenheim DE, Shah MA. Gastric cancer epidemiology and risk factors. J Surg Oncol 2013;107:230-6.

17. Ang TL, Fock KM. Clinical epidemiology of gastric cancer. Singap Med J 2014;55:621-8.

18. Butcher LD, den Hartog G, Ernst PB, Crowe SE. Oxidative stress resulting from Helicobacter pylori infection contributes to gastric carcinogenesis. CMGH 2017;3:316-22.

19. Díaz P, Valderrama MV, Bravo J, Quest AFG. Helicobacter pylori and gastric cancer: adaptive cellular mechanisms involved in disease progression. Front Microbiol 2018;9:1-10.

20. Aydin A, Erenler R, Yılmaz B, Tekin Ş. Antiproliferative effect of Cherry laurel. J Turk Chem Soc Sect A Chem 2016;3:217.

21. Demir S, Turan I, Demir F, Ayazoglu Demir E, Aliyazicioglu Y. Cytotoxic effect of Laurocerasus officinalis extract on human cancer cell lines. Marmara Pharm J 2017;21:121-6.

22. Çakir B, Gülseren I. Investigations on apoptotic activities of cherry laurel extracts in HCT-116 human colon carcinoma cells. Indian J Pharm Educ Res 2019;53:S264-72.

23. Okur ME, Ayla Ş, Çiçek-Polat D, Günal MY, Yoltaş A, Biçeroğlu Ö. Novel insight into wound healing properties of methanol extract of Capparis ovata Desf. var. palaestina Zohary fruits. J Pharm Pharmacol 2018;70:1-13.

24. Spanos GA, Wrolstad RE. Influence of processing and storage on the phenolic composition of Thompson seedless grape juice. J Agric Food Chem 1990;38:1565-71.

25. Singleton VL, Orthofer R, Lamuela-Raventós RM. [14] Analysis of total phenols and other oxidation substrates and antioxidants by means of folin-ciocalteu reagent. Methods Enzymol 1999;299: 152-78.

26. Okur ME, Polat DC, Ozbek H, Yilmaz S, Yoltas A, Arslan R. Evaluation of the antidiabetic property of Capparis Ovata Desf. Var. Paleastina Zoh. Extracts using in vivo and in vitro approaches. Endocr Metab Immune Disord - Drug Targets 2018; 18:489-501.

27. Mihai CM, Mărghitaş L, Bobiş $O$, Dezmirean D, Tămaş $M$. Estimation of flavonoid content in propolis by two different colorimetric methods. Sci Pap Anim Sci Biotechnol 2010;43: 407-10.

28. Blois MS. Antioxidant determinations by the use of a stable free radical [10]. Nature 1958;181:1199-200.

29. Re R, Pellegrini N, Proteggente A, Pannala A, Yang M, Rice-Evans C. Antioxidant activity applying an improved ABTS radical cation decolorization assay. Free Radic Biol Med 1999;26:1231-7.

30. Gulsoy-Toplan G, Goger F, Yildiz-Peko A, Gibbons S, Sariyar G, Mat A. Chemical constituents of the different parts of Colchicum micranthum and C. chalcedonicum and their cytotoxic activities. Nat Prod Commun 2018;13:535-8.

31. Orhan IE, Akkol EK. Estimation of neuroprotective effects of Laurocerasus officinalis Roem. (cherry laurel) by in vitro methods. Food Res Int 2011;44:818-22.

32. Liyana-Pathirana CM, Shahidi F, Alasalvar C. Antioxidant activity of cherry laurel fruit (Laurocerasus officinalis Roem.) and its concentrated juice. Food Chem 2006;99:121-8.

33. Karabegović IT, Stojičević SS, Veličković DT, Todorović ZB, Nikolić NČ, Lazić ML. The effect of different extraction techniques on the composition and antioxidant activity of cherry laurel
(Prunus laurocerasus) leaf and fruit extracts. Ind Crop Prod 2014; 54:142-8.

34. Cai Y, Luo Q, Sun M, Corke H. Antioxidant activity and phenolic compounds of 112 traditional Chinese medicinal plants associated with anticancer. Life Sci 2004;74:2157-84.

35. Celep E, Aydin A, Yesilada E. A comparative study on the in vitro antioxidant potentials of three edible fruits: cornelian cherry, Japanese persimmon and cherry laurel. Food Chem Toxicol 2012; 50:3329-35.

36. Erdemoglu N, Küpeli E, Yeşilada E. Anti-inflammatory and antinociceptive activity assessment of plants used as remedy in Turkish folk medicine. J Ethnopharmacol 2003;89:123-9.

37. Karahalil F, Şahin H. Phenolic composition and antioxidant capacity of cherry laurel (Laurocerasus officinalis Roem.) sampled from Trabzon region, Turkey. Afr J Biotechnol 2011;10:16293-9.

38. Tandon R, Khanna RD, Dorababu M, Goel R. Oxidative stress and antioxidants status in peptic ulcer and gastric carcinoma. Indian J Physiol Pharmacol 2004;48:115-8.

39. Bhattacharyya A, Chattopadhyay R, Mitra S, Crowe SE. Oxidative stress: an essential factor in the pathogenesis of gastrointestinal mucosal diseases. Physiol Rev 2014;94:329-54.

40. Butera D, Tesoriere L, Di Gaudio F, Bongiorno A, Allegra M, Pintaudi AM, et al. Antioxidant activities of Sicilian prickly pear (Opuntia ficus indica) fruit extracts and reducing properties of its betalains: betanin and indicaxanthin. J Agric Food Chem 2002;50: 6895-901.

41. Lee J-C, Kim H-R, Kim J, Jang Y-S. Antioxidant property of an ethanol extract of the stem of Opuntia ficus-indica var. Saboten. J Agric Food Chem 2002;50:6490-6.

42. Boots AW, Haenen GRMM, Bast A. Health effects of quercetin: from antioxidant to nutraceutical. Eur J Pharmacol 2008;585: 325-37.

43. Borska S, Chmielewska M, Wysocka T, Drag-Zalesinska M, Zabel $M$, Dziegiel $P$, et al. In vitro effect of quercetin on human gastric carcinoma: targeting cancer cells death and MDR. Food Chem Toxicol 2012;50:3375-83.

44. Wang K, Liu R, Li J, Mao J, Lei Y, Wu J, et al. Quercetin induces protective autophagy in gastric cancer cells: involvement of Akt-mTOR- and hypoxia-induced factor $1 \alpha$-mediated signaling. Autophagy 2011;7:966-78.

45. Wu B, Zhang Q, Shen W, Zhu J. Anti-proliferative and chemosensitizing effects of luteolin on human gastric cancer AGS cell line. Mol Cell Biochem 2008;313:125-32.

46. Wu H, Huang M, Liu Y, Shu Y, Liu P. Luteolin induces apoptosis by up-regulating miR-34a in human gastric cancer cells. Technol Canc Res Treat 2015;14:747-55.

47. Shukla S, Gupta S. Apigenin: a promising molecule for cancer prevention. Pharm Res 2010;27:962-78.

48. Kuo C-H, Weng B-C, Wu C-C, Yang SF, Wu DC, Wang YC. Apigenin has anti-atrophic gastritis and anti-gastric cancer progression effects in Helicobacter pylori-infected Mongolian gerbils. J Ethnopharmacol 2014;151:1031-9.

49. Hirobe C, Qiao Z-S, Takeya K, Itokawa H. Cytotoxic flavonoids from Vitex agnus-castus. Phytochemistry 1997;46:521-4.

50. Seelinger G, Merfort I, Wölfle U, Schempp CM. Anti-carcinogenic effects of the flavonoid luteolin. Molecules 2008;13:2628-51. 